\title{
PENGARUH RENTABILITAS, EFISIENSI DAN LIKUIDITAS TERHADAP KECUKUPAN MODAL BANK UMUM SYARIAH
}

\begin{abstract}
Siti Fatimah1
Abstract. The Influence of Rentability, Efficiency, Liquidity To Capital Adequacy Ratio in Islamic Bank: Study at PT Bank Syariah Mandiri. The aim of this study is to analyze the influence of rentability (ROA), efficiency (BOPO), and liquidity (FDR) to Capital Adequacy Ratio (CAR) in short-run and long-run. The method analysis that used in this study is VECM method. The result was shown that ROA had a significant negative influence to CAR, BOPO had a significant positive influence to CAR, and FDR had a significant negative influence to CAR. There were a long-run correlation between BOPO and FDR to CAR, and there were a short-run correlation between ROA, $B O P O, F D R$ to $C A R$.
\end{abstract}

Keywords. Rentability, Efficiency, Liquidity, Capital Adequacy, VECM

Abstrak. Pengaruh Rentabilitas, Efisiensi, dan Likuiditas Terhadap Kecukupan Modal Bank Umum Syariah: Study Pada PT Bank Syariah Mandiri Tbk. Penelitian ini bertujuan untuk menganalisis seberapa besar pengaruh rentabilitas (ROA), efisiensi (BOPO) dan likuiditas (FDR) terhadap kecukupan modal (CAR) dalam jangka pendek maupun jangka panjang. Metode yang digunakan yaitu metode kuantitatif dengan alat analisis menggunakan metode analisis VECM. Hasil penelitian menyatakan ROA berpengaruh negatif signifikan terhadap CAR, BOPO berpengaruh positif signifikan dan FDR berpengaruh negatif signifikan terhadap CAR Selain itu, terdapat hubungan jangka panjang antara BOPO dan FDR terhadap CAR, sedangkan dalam jangka pendek terdapat hubungan antara ROA, BOPO dan FDR terhadap CAR.

Kata Kunci: Rentabilitas, Efisiensi, Likuiditas, Kecukupan Modal, VECM

\footnotetext{
${ }^{1}$ Naskahditerima 15 Oktober 2013, Direvisi 20 Nopember 2013, disetujui 24 Nopember 2013 BCA Finance, BCA Pondok Indah Lt. 2, Jl. Metro Pondok Indah, No. 10, Jakarta.

Email: fatimahsitti86@yahoo.com
} 


\section{PENDAHULUAN}

Berkembangnya bank syariah di Indonesia harus dibarengi dengan peningkatan kualitas dan kuantitas bank syariah, agar lebih mendapatkan kepercayaan dimata nasabahnya. Salah satu upaya untuk menjaga eksistensi bank syariah, pihak manajemen perlu memperhatikan kriteria pengukuran kesehatan dan kinerja perbankan. Salah satu indikator kesehatan perbankan yang sangat penting yaitu indikator modal.

Indikator modal perbankan harus dikedepankan mengingat dalam mekanismenya perbankan merupakan industri yang usahanya mengandalkan kepercayaan masyarakat. Kesehatan bank yang dapat dilihat dengan indikator modal sudah seharusnya dilihat masyarakat untuk membangun kepercayaan dalam meyerahkan dananya pada bank. Hal ini mengingat citra perbankan nasional yang ternodai oleh berbagai kasus penyelewengan dana nasabah oleh pihak manajamen bank, maupun masalah perbankan yang tidak liquid.

Demi menciptakan perbankan yang sehat, BI telah mengeluarkan program Arsitektur Perbankan Indonesia (API) yaitu program penguatan struktur perbankan nasional yang bertujuan untuk memperkuat permodalan bank dalam rangka meningkatkan kemampuan bank mengelola usaha maupun risiko. Upaya pemerintah yang lain yaitu dengan dikeluarkanya Peraturan Bank Indonesia Nomor: 6/10/PBI/2004 tentang Sistem Penilaian Tingkat Kesehatan Bank Umum. Ketentuan yang salah satu diantaranya adalah mengatur tentang permodalan Bank ( CAR) minimum sebesar $8 \%$ (delapan persen).

Pada tahun 2011 total asset bank syariah hanya 2,6\% dibandingkan dengan bank umum. Tetapi pada 2012 jumlah perbandingan total asetnya naik menjadi 3,24\%. Perbandingan antara tahun 2011 dan 2012 total aset dari bank umum sendiri naik 20,3\% sementara total aset dari bank syariah naik 47,4\%. Peningkatan aset bank syariah ditunjang dengan banyaknya bank umum syariah di Indonesia hingga saat ini, dengan Bank Syariah Mandiri sebagai bank umum syariah dengan aset terbesar yaitu senilai Rp 49,70 triliun per Juni 2012.

Berdasarkan peraturan pemerintah mengenai tingkat kesehatan bank umum, setiap bank berusaha untuk menjaga nilai CAR perusahaanya dengan tujuan untuk mempertahankan tingkat kesehatan Bank tersebut. Dalam implementasinya Bank Syariah Mandiri sebagai bank dengan aset terbesar tetap mengalami fluktuasi dalam perkembangan kecukupan modalnya. Hal ini terlihat dari nilai CAR Bank Umum Syariah periode pengamatan 2009-2012 pada tabel 1 berikut ini:

\section{Tabel 1}

CAR Bank Syariah Mandiri

Periode 2009-2012(Dalam \%)

\begin{tabular}{ccccc}
\hline Tahun & $\mathbf{2 0 0 9}$ & $\mathbf{2 0 1 0}$ & $\mathbf{2 0 1 1}$ & $\mathbf{2 0 1 2}$ \\
\hline CAR & 13,67 & 11,78 & 12,24 & 13,69 \\
\hline
\end{tabular}

Sumber: Laporan Keuangan Bank Syariah Mandiri (data diolah kembali)

Berdasarkan tabel diatas dapat dilihat bahwa CAR Bank Syariah Mandiri tahun 2009-2012 mengalami perubahan naik turun namun tetap dalam kondisi sehat karena berada diatas 8\%. Selain itu, dari data diatas terlihat bahwa CAR Bank Syariah Mandiri tahun 2009 hingga 2011 mengalami penurunan. Namun terlihat pada tahun 2012 CAR Bank Syariah Mandiri kembali meningkat. 
Pergerakan CAR yang fluktuatif tersebut perlu dilakukan tindak lanjut oleh pihak manajemen agar mengetahui faktor-faktor apa saja yang mempengaruhi perubahan CAR tersebut.

Sebagai bank umum syariah dengan aset terbesar Bank Syariah Mandiri tetap membutuhkan tambahan modal. Hal tersebut diperlukan untuk mendukung kesinambungan ekspansi pembiayaan pada tahun berikutnya. Rasio kecukupan modal (CAR), bank syariah terbesar di Indonesia ini kerap tergerus secara cepat akibat ekspansi pembiayaan yang tinggi.

Menurut Zainal Fanani, Direktur Kepatuhan sekaligus Chief Financial Officer BSM, mengatakan perseroan menargetkan ekspansi pembiayaan sebesar 25\% selama tahun ini, dibandingkan dengan akhir 2011 Rp36,72 triliun. Pada akhir 2011 CAR BSM 14,57\% dan dengan perkembangan bisnis selama tahun 2012 pihak BSM meprediksi CAR bisa dipertahankan di atas 12\%. Selama 2011 CAR BSM meningkat dari 10,6\% menjadi 14,57\%, yang ditopang oleh suntikan modal dari Bank Mandiri sebesar Rp500 miliar yang diberikan dua kali, yakni pada pertengahan Maret 2011 dan akhir Desember 2011. Penambahan modal itu meningkatkan modal disetor BSM menjadi Rp1,16 triliun pada akhir 2011, dibandingkan dengan 2010 yang tercatat Rp658,24 triliun.

Pemilihan variabel CAR sebagai variabel dependen dikarenakan CAR merupakan indikator yang sangat penting menurut Bank Indonesia dalam menjaga tingkat kesehatan bank. Dimana Capital Adequacy Ratio (CAR) adalah rasio kinerja bank sebagai pengukur kecukupan modal yang dimiliki bank untuk menunjang aktiva yang mengandung atau menghasilkan risiko, misalnya kredit yang diberikan. CAR merupakan indikator terhadap kemampuan bank untuk menutupi penurunan aktivanya sebagai akibat dari kerugian-kerugian bank yang disebabkan oleh aktiva yang berisiko (Dendawijaya, 2005).

Melihat fenomena perbankan di Indonesia yang mengalami tidak likuid karena tingkat CAR yang tidak mencukupi, dapat dilihat bahwa terdapat hubungan antara rasio likuiditas dengan CAR. Dimana likuiditas merupakan kemampuan bank dalam memenuhi kewajiban jangka pendeknya saat ditagih (Kasmir, 2009). Dalam hal ini, likuiditas tersebut dijelaskan oleh Financing to Deposit Ratio (FDR) yaitu rasio antara seluruh jumlah pembiayaan yang diberikan dengan dana yang diterima bank (Dendawijaya, 2005).

FDR menyatakan seberapa jauh kemampuan bank dalam membayar kembali penarikan dana yang dilakukan deposan dengan mengandalkan pembiayaan yang diberikan sebagai sumber likuiditasnya. Berdasarkan pengertian tersebut, dapat dilihat hubungan FDR dengan CAR yaitu, saat FDR tinggi yang disebabkan pembiayaan tinggi sedangkan dana yang dihimpun sedikit dapat menyebabkan CAR menurun (dengan asumsi CAR digunakan untuk menutupi kekurangan dana tersebut). Hal ini sesuai dengan pendapat Dahlan Siamat yang mengemukakan bahwa faktor-faktor yang dipertimbangkan dalam menilai kecukupan modal bank antara lain adalah likuiditas (Siamat, 2004).

Rasio rentabilitas yang dilihat dengan menggunakan Return on Assets (ROA). ROA adalah rasio yang digunakan untuk mengukur kemampuan manajemen bank dalam memperoleh keuntungan (laba) secara keseluruhan. Semakin besar ROA suatu bank, semakin besar pula tingkat keuntungan yang 
dicapai bank tersebut dan semakin baik pula posisi bank tersebut dari segi penggunaan asset.

Berdasarkan pengertian tersebut, apabila laba suatu bank meningkat maka akan meningkatkan modal bank tersebut pula, dengan asumsi laba tersebut ditanamkan kembali ke dalam modal bank dalam bentuk laba ditahan. Hal ini senada dengan pendapat Ali (2006) yang menyatakan setiap kali bank mengalami kerugian, modal bank menjadi berkurang nilainya dan sebaliknya jika bank meraih untung maka modalnya akan bertambah.

BOPO merupakan rasio perbandingan biaya operasional terhadap pendapatan operasional. Rasio ini digunakan untuk mengukur tingkat efisiensi dan kemampuan bank dalam melakukan kegiatan operasinya terutama kredit (Dendawijaya, 2005). Sama halnya dengan ROA, secara teoritis BOPO juga memiliki hubungan dengan CAR, dengan asumsi semakin efisien bank menghasilkan laba melalui biaya operasionalnya, semakin meningkat pula modal yang ditanamkannya.

Selain itu BOPO yang tinggi menunjukan kurangnya efisien bank dalam menjalankan kegiatan operasionalnya karena biaya operasional yang harus ditanggung lebih besar daripada pendapatan operasional yang diperoleh sehingga ada kemungkinan modal digunakan untuk menutupi biaya operasional yang tidak tertutup oleh pendapatan operasional (Abdullah, 2003).

Berdasarkan uraian diatas kondisi pertumbuhan bank syariah yang lebih cepat dibandingkan Bank Konvensional, diperlukan penelitian mengenai kesehatan bank yang salah satunya menggunakan indikator kecukupan modal. Oleh karena itu, tujuan yang ingin dicapai dalam penelitian ini yaitu:

1. Menganalisis pengaruh rentabilitas, efisiensi dan likuiditas terhadap kecukupan modal Bank Umum Syariah.

2. Menganalisis hubungan rentabilitas, efisiensi dan likuiditas dalam jangka pendek maupun jangka panjang terhadap kecukupan modal Bank Umum Syariah.

\section{TINJAUAN PUSTAKA}

\section{Rasio Keuangan Bank}

Salah satu cara untuk menguji kecukupan modal adalah dengan melihat rasio modal itu terhadap berbagai aset bank yang bersangkutan. Dimana, rasio kecukupan modal bank adalah rasio yang digunakan untuk mengukur kemampuan bank mencari sumber dana untuk membiayai kegiatannya. Salah satu penilaian modal perbankan yaitu dengan menganalisis rasio permodalanya yang dijelaskan dengan CAR (Capital Adequecy Ratio). Penilaian tersebut dapat diukur dengan dua cara yaitu membandingkan modal dengan dana-dana pihak ketiga dan membandingkan modal dengan aktiva berisiko.

Menurut R. Arif Ginanjar dalam penelitiannya menyebutkan terdapat delapan faktor yang mempengaruhi kecukupan modal. Faktor tersebut yaitu: kualitas manajemen, likuiditas aset, riwayat laba dan riwayat laba yang ditahan, kualitas dan sifat kepemilikan, potensi perubahan struktur aset, kualitas prosedur operasi, kemampuan untuk memenuhi kebutuhan keuangan, dan beban untuk menutupi biaya penempatan.

Capital Adequacy Ratio (CAR) adalah rasio kewajiban pemenuhan modal minimum yang harus dimiliki oleh Bank (Riyadi, 2004). CAR merupakan indikator terhadap kemampuan bank untuk menutupi penurunan aktivanya sebagai akibat dari kerugian-kerugian bank yang disebabkan oleh aktiva yang berisiko 
(Dendawijaya, 2005). CAR dapat dihitung dengan membandingkan modal terhadap aktiva tertimbang menurut risiko (ATMR). CAR dapat dihitung menggunakan rumus berikut (Dendawijaya, 2005):

$$
\mathrm{CAR}=\underline{\text { Modal }}_{\text {ATMR }} \mathrm{X} \text { 100\% }
$$

BI menetapkan ketentuan modal minimum bagi perbankan sebagaimana ketentuan dalam standar Bank for International Settlements (BIS) bahwa setiap bank umum diwajibkan menyediakan modal minimum sebesar $8 \%$ dari total aktiva tertimbang menurut risiko (ATMR).

Rentabilitas rasio sering juga disebut profitabilitas usaha. Dimana rentabilitas adalah aspek yang digunakan untuk mengukur kemampuan bank dalam meningkatkan keuntungan. Salah satu rasio yang digunakan untuk mengukur tingkat rentabilitas bank ialah ROA (Return on Assets). Rentabilitas bank sangat penting, dimana, laba sebagai sumber dana bank yang utama dalam meningkatkan modal inti, sangat tergantung pada kemampuan rentabilitas (earning power).

ROA menunjukan kemampuan bank dalam memperoleh keuntungan (laba) secara keseluruhan dari aset yang dimiliki. Semakin besar ROA suatu bank, semakin besar pula tingkat keuntungan yang dicapai bank tersebut dan semakin baik pula posisi bank tersebut dari segi penggunaan aset. Sebaliknya, Semakin kecil ROA suatu bank, semakin kecil keuntungan yang dicapai bank tersebut dan semakin kecil pula posisi bank tersebut dari segi penggunaan aset.

Efisiensi bank adalah kemampuan bank untuk menggunakan faktor -faktor produksi secara tepat atau efektif. Pengukuran tingkat efisiensi bank dapat dilakukan dengan menganalisis rasio BOPO.

BOPO merupakan rasio perbandingan biaya operasional terhadap pendapatan operasional. BOPO menurut kamus keuangan adalah kelompok rasio yang mengukur efisiensi dan efektivitas operasional suatu perusahaan dengan jalur membandingkan yang satu terhadap yang lainnya. Rasio ini digunakan untuk mengukur tingkat efisiensi dan kemampuan bank dalam melakukan kegiatan operasinya, terutama kredit.

Semakin kecil BOPO menunjukan semakin efisien bank dalam menjalankan aktivitas usahanya. Begitupun sebaliknya, semakin besar nilai BOPO semakin tidak efisien bank dalam menjalankan aktivitas usahanya.

Likuiditas menunjukan persediaan uang tunai dan aset lain yang dengan mudah dijadikan uang tunai. Oleh karena itu, likuiditas adalah suatu keadaan yang berhubungan dengan persediaan uang tunai dan alat-alat likuid lainnya yang dikuasai bank yang bersangkutan. Likuiditas bank adalah kemampuan bank untuk membayar hutang jangka pendeknya (Kasmir, 2008).

Salah satu ukuran likuid dari konsep persediaan adalah rasio pinjaman terhadap pembiayaan yang diukur dengan FDR. FDR ialah rasio antara seluruh jumlah pembiayaan yang diberikan bank dengan dana yang diterima oleh bank. FDR menyatakan seberapa jauh kemampuan bank dalam membayar kembali penarikan dana yang dilakukan deposan dengan mengandalkan pembiayaan yang diberikan sebagai sumber likuiditasnya. Dengan kata lain, seberapa jauh pemberian pembiayaan kepada nasabah dapat mengimbangi kewajiban bank 
untuk segera memenuhi permintaan deposan yang ingin menarik kembali uangnya yang telah digunakan oleh bank untuk memberikan pembiayaan.

Semakin tinggi FDR, maka semakin rendah kemampuan likuiditas bank tersebut. Selain mencerminkan kondisi likuiditas bank, rasio ini juga digunakan untuk mengukur tingkat risiko yang menjadi beban bank dalam menjalankan usahanya (Suhirman, 2001).

\section{Pengaruh Rasio Keuangan terhadap Kecukupan Modal}

Rasio keuangan yang sering digunakan perbankan terdiri dari beberapa rasio seperti rasio likuiditas, rasio rentabilitas, rasio efisiensi, rasio solvabilitas dan rasi kecukupan modal. Adapun dalam penelitian ini hanya mengulas pengaruh rentabilitas, efisiensi dan likuiditas terhadap kecukupan modal bank umum syariah. Pengaruh rasio-rasio tersebut terhadap kecukupan modal bank diuraikan sebagai berikut:

CAR merupakan indikator terhadap kemampuan bank untuk menutupi penurunan aktivanya sebagai akibat dari kerugian-kerugian bank yang disebabkan oleh aktiva yang berisiko. Dapat diduga, apabila laba suatu bank meningkat maka akan meningkatkan modal bank tersebut pula, dengan asumsi laba tersebut ditanamkan kembali ke dalam modal bank dalam bentuk laba ditahan.

Hal tersebut senada dengan yang dikemukakan oleh Ali (2006) bahwa setiap kali bank mengalami kerugian, modal bank menjadi berkurang nilainya dan sebaliknya jika bank meraih untung maka modalnya akan bertambah. Pendapat tersebut juga didukung dengan hasil penelitian F. Artin Shitawati (2006) yang menyebutkan bahwa ROA secara parsial berpengaruh signifikan positif terhadap CAR.

Selain itu, dilihat dari hubungan laba, asset dan modal yaitu jika laju pertumbuhan laba dan asset berjalan lambat, maka bank yang bersangkutan akan menghadapi risiko yang lebih besar dibandingkan dengan bank yang mengalami pertumbuhan yang sehat. Oleh karena itu, untuk mengatasi risiko yang lebih besar dari itu, maka diperlukan modal yang lebih besar.

Semakin besar BOPO menunjukan kurang efisiennya bank dalam menjalankan kegiatan operasionalnya karena biaya operasional yang harus ditanggung lebih besar dari pada pendapatan operasional yang diperoleh sehingga ada kemungkinan modal digunakan untuk menutupi biaya operasional yang tidak tertutup oleh pendapatan operasional (Abdullah, 2003).

Sebaliknya, semakin kecil BOPO menunjukan semakin efisiennya bank dalam menjalankan kegiatan operasionalnya, karena biaya operasional yang harus ditanggung lebih kecil dari pada pendapatan operasionalnya. Sehingga aktivitas operasional bank menghasilkan keuntungan, dimana hal tersebut mampu meningkatkan modal bank dan meminimumkan tingkat risikonya. Selain itu, hubungan BOPO dengan CAR dapat dilihat semakin efisien bank menghasilkan laba melalui biaya operasionalnya, semakin meningkat pula modal yang ditanamkannya. Sehingga dapat dilihat hubungan negatif antara BOPO dengan CAR. Saat BOPO tinggi akan menurunkan CAR, dan begitupun sebaliknya. Saat BOPO rendah akan meningkatkan CAR. Hal ini, sesuai dengan hasil penelitian F. Artin Shitawati (2006) yang menyebutkan bahwa secara parsial BOPO berpengaruh signifikan negatif terhadap CAR.

FDR merupakan rasio likuiditas yang sering digunakan bank. FDR ini dapat mengukur jumlah pembiayaan yang diberikan bank dengan dana yang diterima oleh bank. FDR yang rendah menunjukan jumlah pembiayaan yang diberikan lebih 
kecil dari pada pertumbuhan jumlah dana yang dihimpun. Begitupun sebaliknya, FDR yang tinggi menunjukan pertumbuhan jumlah pembiayaan yang diberikan lebih besar dari pada pertumbuhan jumlah dana yang dihimpun sehingga mengindikasikan semakin rendahnya kemampuan likuiditas bank. Hal ini disebabkan karena jumlah dana yang diperlukan untuk membiayai pembiayaan semakin besar.

Suatu bank yang memiliki alat-alat likuid yang sangat terbatas dalam memenuhi kewajiban-kewajibannya, akan ada kemungkinan penyediaan likuiditas tersebut akan diambil dari permodalannya (Abdullah, 2003). Hal ini juga sesuai dengan hasil penelitian F. Artin Shitawati (2006) yang menyebutkan bahwa FDR secara parsial berpengaruh negatif dan signifikan terhadap CAR Bank Umum Syariah. Selain itu, dapat dilihat hubungan FDR dengan CAR yaitu, saat FDR tinggi yang disebabkan pembiayaan tinggi sedangkan dana yang dihimpun sedikit dapat menyebabkan CAR menurun (dengan asumsi CAR digunakan untuk menutupi kekurangan dana tersebut).

\section{METODE}

Ruang lingkup penelitian ini adalah Bank Syariah Mandiri.Penelitian ini bertujuan untuk menganalisis pengaruh variabel independen (bebas) terhadap variabel dependen (terikat). Adapun variabel dependen (Y) penelitian ini adalah kecukupan modal yang dijelaskan oleh CAR. Sedangkan variabel independennya $(\mathrm{X})$ terdiri dari tiga variabel yaitu rentabilitas yang dijelaskan oleh ROA ( $\left.\mathrm{X}_{1}\right)$, efisiensi oleh BOPO $\left(\mathrm{X}_{2}\right)$ dan likuiditas oleh FDR $\left(\mathrm{X}_{3}\right)$. Periode penelitian ini Januari 2009 sampai dengan Desember 2012.

Teknik yang digunakan untuk menganalisis data ialah metode analisis VECM (Vektor Error Corection Model). Dimana metode analisis VECM menurut Kostiv dan Lingard yang dikutip Rohmatul (2011) menjelaskan bahwa VECM merupakan suatu metode analisis yang dapat digunakan untuk mengetahui tingkah laku jangka pendek dari suatu variabel terhadap jangka panjangnya, akibat adanya shock (perubahan) yang permanen.

Asumsi yang harus dipenuhi dalam analisis VECM adalah semua variabel independen harus stasioner. Jika dalam uji stasioner data belum menunjukan stasioner dapat diestimasi sehingga data stasioner pada tingkat diferensiasi. Selain stasioner variabel, hal penting lain dalam analisis VECM ialah kointegrasi yang menjelaskan hubungan jangka pendek dan jangka panjang antarvariabel. Jika variabel stasioner dan tidak terkointegrasi dapat menggunakan model analisis VAR, tapi jika variabel stasioner pada tingkat diferensiasi dan terkointegrasi model analisis yang digunakan ialah VECM.

VECM juga dapat digunakan untuk menghitung hubungan jangka pendek antarvariabel melalui koefisien standard dan mengestimasi hubungan jangka panjang dengan menggunakan lag residual dari regresi yang terkointegrasi. Secara umum, model Hoffman dan Rasche (1997) menjelaskan tentang model estimasi VECM untuk data time series $\mathrm{X}_{\mathrm{t}}$ vector $(p \times \mathrm{x}$ 1) yang terkointegrasi tiap komponennya dalam bentuk persamaan dibawah ini:

$$
\Delta \mathrm{Xt}=\mu+\alpha \beta^{\prime} \mathrm{X}_{\mathrm{t}-1}+\sum_{i=1}^{k} \mathrm{~F}_{1} \Delta \mathrm{X}_{\mathrm{t}-1}+\epsilon_{\mathrm{t}}
$$

\section{Dimana:}

$\mathrm{F}_{1} \quad$ : koefisien matriks $(p \times p): \mathrm{I}=1, \ldots, k$

$\mu$ : vektor $(p \times 1)$ yang meliputi seluruh komponen deteriminan dalam sistem 
$\alpha, \beta$ : matriks $(p \times r) ; 0<r<p$ dan $r$ merupakan jumlah kombinasi linear elemen $X_{t}$ yang hanya dipengaruhi oleh shock transistor

$\beta^{\prime} X_{\mathrm{t}-1}$ : error correction term, yaitu jumlahpenmberat pembalik rata-rata pada vector kointegrasi data ke $\mathrm{t}-1$

$\alpha$ : matriks dari koefisien error correction.

Langkah-langkah yang dilakukan dalam analisis VECM terdiri dari beberapa langkah, yaitu;

\section{Uji Asumsi Klasik}

Sebelum data diolah dan mengeluarkan hasilnya, data harus di uji terlebih dahulu. Uji data tersebut yaitu, uji asumsi klasik yang terdiri dari uji normalitas, multikolinearitas, uji autokorelasi dan uji heteroskedastisitas.

Normalitas bertujuan untuk menguji apakah variabel bebas, variabel tidak bebas, atau keduanya mempunyai distribusi normal atau tidak. Salah satu cara untuk melihat normalitas residual adalah dengan menggunakan metode jarquebera (JB). Jika probabilitas $\mathrm{OBS}^{*} \mathrm{R}^{2}$ lebih besar dari 0,05 maka model tersebut dikatakan normal. Apabila $0 B S^{*} \mathrm{R}^{2}$ lebih kecil dari 0,05 maka model tersebut dikatakan tidak normal.

Multikolinearitas adalah hubungan linear antarvariabel bebas. Sehingga uji multikolinearitas ini dibutuhkan untuk mengetahui ada atau tidaknya hubungan linear antarvariabel bebas tersebut. Uji multikolinearitas pada penelitian ini menggunakan koefisien korelasi. Dimana, Salah satu cara untuk mendeteksi terjadinya multikolinearitas yaitu dengan menggunakan matriks korelasi (correlation matrix).

Jika hubungan antara variabel bebas yang satu dengan yang lainnya diatas 0,85 maka antarvariabel tersebut terdapat gejala multikolinearitas. Begitupun sebaliknya, jika hubungan antara variabel bebas yang satu dengan yang lainnya dibawah 0,85 maka antarvariabel tersebut tidak terdapat gejala multikolinearitas.

Uji ini bertujuan untuk menguji apakah terdapat kesamaan variance dari residual satu pengamatan kepengamatan lain. Jika probabilitas $0 B{ }^{*} \mathrm{R}^{2}$ lebih besar dari 0,05 maka model tersebut tidak terdapat Heteroskedastisitas. Apabila OBS* $\mathrm{R}^{2}$ lebih kecil dari 0,05 maka model tersebut terdapat Heteroskedastisitas.

Autokorelasi adalah hubungan antara residual satu observasi dengan residual observasi lainnya. Oleh karena itu, uji autokorelasi bertujuan untuk melihat ada atau tidaknya hubungan antara residual satu observasi dengan residual observasi lainnya.Dalam penelitian ini, uji autokorelasi menggunakan metode Uji Breusch-Godfrey.

Jika nilai probabilitas lebih kecil dari 0,05 maka dapat disimpulkan bahwa terdapat masalah autokorelasi pada model tersebut. Selain itu, jika terdapat masalah autokorelasi dapat diatasi dengan meningkatkan standar diferensiasi dari tingkat dasar menjadi tingkat 1.

\section{Uji Stasioneritas}

Uji stasioneritas sangat penting bagi data time series dan uji ini dilakukan sebelum data dianalisis. Sekumpulan data dinyatakan stasioner jika nilai rata-rata dan varian dari data time series tersebut tidak mengalami perubahan secara sistematik sepanjang waktu sehingga data tersebut konstan. Dalam penelitian ini menggunakan metode uji akar unit agar mendapatkan hasil yang lebih akurat. Jika nilai probabilitas lebih kecil dari 0,05 maka dapat disimpulkan bahwa data stasioner. Sedangkan jika nilai probabilitas lebih besar dari 0,05 maka data tidak 
stasioner. Jika data tidak stasioner dilevel normal, data dapat dinaikan ke diferensiasi tingkat 1.

\section{Uji Lag Length}

Uji lag length bertujuan untuk mengetahui lag optimal yang digunakan dalam model penelitian. Hal ini dikarenakan jika lag yang digunakan terlalu sedikit, maka residual dari regresi tidak akan menampilkan proses white noise sehingga model tidak dapat mengestimasi actual error secara tepat. Akibatnya standar kesalahan tidak diestimasi secara baik. Selain itu jika memasukan lag terlalu banyak akan mengurangi kemampuan menolak Ho dan dapat mengurangi derajat kebebasan.

\section{Uji Kausalitas Granger}

Uji kausalitas granger bertujuan untuk melihat apakah suatu variabel mempunyai hubungan dua arah atau hanya satu arah saja. Pada uji ini yang dilihat adalah pengaruh masa lalu terhadap kodisi sekarang, sehingga data yang digunakan adalah data time series. Hubungan kausalitas antarvariabel dapat dilihat menggunakan nilai probabilitasnya. Jika nilai probabilitas masing-masing variabel lebih kecil daripada nialai $\alpha$, maka dapat dinyatakan terdapat hubungan kausalitas antar variabel. Begitupun sebaliknya, jika nilai probabilitas lebih besar dari 0,05 maka tidak terdapat hubungan kausalitas antar varabel.

\section{Uji Kointegrasi}

Uji kointegrasi dilakukan untuk mendeteksi stabilitas hubungan jangka panjang dua variabel atau lebih. Kointegrasi adalah suatu hubungan jangka panjang atau ekuilibrium antara variabel-variabel yang tidak stasioner. Dengan kata lain, walau secara individual variabel-variabel tersebut tidak stasioner, namun kombinasi antar variabel tersebut bisa menjadi stasioner. Jika nilai Trace Statisticnya lebih kecil dibanding nilai kritis pada tingkat keyakinan 5\% maupun $1 \%$ dapat disimpulkan bahwa antar variabel tidak saling berkointegrasi.

\section{Estimasi VECM}

Berdasarkan tujuan analisis VECM yaitu untuk mengetahui tingkah laku jangka pendek dari suatu variabel terhadap jangka panjangnya, akibat adanya shock (perubahan) yang permanen, maka estimasi yang dapat digunakan sebagai bentuk dari persamaan sebelumnya dengan membaca hasil olahan data. Dimana, jika nilai t-statistik hasil estimasi lebih besar daripada nilai t-tabelnya, maka dapat dikatakan terdapat hubungan jangka panjang atau jangka pendek. Sedangkan, jika nilai t-statistik hasil estimasi lebih kecil daripada nilai t-tabelnya, maka dapat dikatakan tidak terdapat hubungan jangka panjang atau jangka pendek.

\section{Uji IRF}

IRF berfungsi menggambarkan ekspektasi k-periode ke depan dari kesalahan prediksi suatu variabel akibat inovasi dari variabel yang lain. Degan demikian, lamanya pengaruh dari shock suatu variabel terhadap variabel lain sampai pengaruhnya hilang atau kembali ke titik seimbangnya dapat dilihat atau diketahui. Sehingga, uji ini bertujuan untuk melihat gambaran pergerakan variabel yang disebabkan adanya shock variabel lain. Respon variabel terikat terhadap variabel bebasnya dapat digambarkan dalam grafik IRF itu sendiri. Jika grafik IRF berada diatas titik keseimbangan maka respon variabel yang dianalisis adalah positif. Sedangkan, jika grafik IRF berada dibawah titik keseimbangan maka variabel yang dianalisis memberikan respon negatif atau mengalami penurunan. 


\section{Uji Variance Decomposition}

Variance Decomposition atau disebut juga forecast error variance decompotition merupakan perangkat dalam model VAR yang akan memisahkan variasi dari sejumlah variabel yang diestimasi menjadi variabel innovation, dengan asumsi bahwa variabel-variabel innovation tidak saling berkorelasi. Setelah variabel tersebut terpisah, kemudian variabel decompotion akan memberikan informasi mengenai proporsi dari pergerakan pengaruh shock pada sebuah variabel terhadap shock variabel lainnya pada periode saat ini dan yang akan datang.

\section{PEMBAHASAN}

\section{Uji Asumsi Klasik}

\section{- Uji Normalitas}

Dari tabel 2 dapat dilihat bahwa nilai probabilitasnya CAR sebesar 0,316486, ROA sebesar 0,335976, BOPO sebesar 0,006516 dan FDR sebesar 0,523212. Nilai probabilitas keempat variabel tersebut $>$ dari derajat kesalahan $(\alpha) 5 \%$ yaitu (0.05) maka $\mathrm{H}_{\mathrm{o}}$ ditolak, sehingga data tersebut dinyatakan terdistribusi normal sehingga bisa dilanjutkan kepengujian yang lainnya.

\section{Tabel 2}

Hasil Uji Normalitas

\begin{tabular}{ccccc}
\hline & Y & X1 & X2 & X3 \\
Probability & 0.316486 & 0.335976 & 0.006516 & 0.523212 \\
\hline
\end{tabular}

Sumber: Output Eviews 6 (data diolah)

\section{- Uji Multikolinearitas}

Berdasarkan tabel 3 dapat dilihat bahwa nilai korelasi variabel independen antara $\mathrm{X}_{1}$ (ROA) dan $\mathrm{X}_{2}$ (BOPO) sebesar -0,517396, antara $\mathrm{X}_{1}$ (ROA) dan $\mathrm{X}_{3}$ (FDR) sebesar 0,241364, antara $X_{2}$ (BOPO) dan $X_{3}$ (FDR) sebesar 0,592355.Nilai korelasi variabel independen (ROA, BOPO dan FDR) tertinggi hanya mencapapai 0,241364 yaitu antara $\mathrm{X}_{1}(\mathrm{ROA})$ dan $\mathrm{X}_{3}$ (FDR) . Karena nilai nilai $0.2431364<0.85$ maka diputuskan $\mathrm{H}_{\mathrm{o}}$ ditolak, sehingga dapat dikatakan tidak terdapat multikolinieritas. Hasil tersebut menyatakan bahwa vaiabel bebas penelitian ini terbebas dari gejala multikolinieritas.

Tabel 3. Hasil Uji Multikolinearitas

\begin{tabular}{cccc}
\hline & X1 ROA & X2 BOPO & X3 FDR \\
\hline X1 ROA & 1.000000 & -0.517396 & 0.241364 \\
X2 BOPO & -0.517396 & 1.000000 & -0.592355 \\
X3 FDR & 0.241364 & -0.592355 & 1.000000 \\
\hline
\end{tabular}

Sumber: Output EViews 6 (data diolah)

- Uji Heteroksedasitas

Berdasarkan hasil yang didapat, data membentuk pola tertentu sehingga dapat dikatakan data tersebut tidak bersifat heteroskesdatisitas melainkan bersifat homoskesdatisitas. Sedangkan dalam uji park masalah heteroskedastisitas dilihat melalui nilai probabilitas $0 B S^{*} R^{2}$. Setelah diolah, dapat dilihat nilai probabilitas CAR sebesar 0,6860, ROA sebesar 0,1109, BOPO sebesar 0,1320 dan FDR sebesar 0,5547 yang artinya nilai probabilitas keempat variabel tersebut lebih besar dari 0,05 sehingga dapat disimpulkan 
data tidak bersifat heteroksedastisitas melainkan bersifat homoksedastisitas sehingga Ho ditolak.

- Uji Autokorelasi

Berdasarkan tabel 4 diperoleh nilai probabilitas sebesar 0.4794 setelah diestimasi, dan karena nilai probabilitas lebih besar dari 0,05 maka dapat disimpulkan $\mathrm{H}_{0}$ ditolak dan tidak terdapat masalah autokorelasi pada model tersebut.

Tabel 4. Hasil Uji Breusch-Godfrey setelah diestimasi

\begin{tabular}{lrll}
\hline Breusch-Godfrey Serial Correlation LM Test: & \\
F-statistic & 0.748613 & Prob. F(2,41) & 0.4794 \\
Obs*R-squared & 1.655863 & Prob. Chi-Square(2) & 0.4370 \\
\hline
\end{tabular}

\section{Uji Stasioneritas}

Sumber: Output EViews 6 (data diolah)

Berdasarkan tabel 5 dapat dilihat bahwa nilai probabilitas variabel penelitian pada tingkat diferensiasi 1 yaitu CAR sebesar 0,000, ROA sebesar 0,000, BOPO sebesar 0,000 dan FDR sebesar 0,0000 dimana hal itu menunjukan bahwa nilai probabilitas keempat variabel tersebut lebih kecil dari 0,05 , sehingga $\mathrm{H}_{\mathrm{o}}$ ditolak. Hal tersebut menjelaskan bahwa variabel CAR, ROA, BOPO dan FDR stasioner dengan tingkat diferensiasi 1.

\begin{tabular}{|c|c|}
\hline ADF test & Prob.* \\
\hline CAR & 0.0000 \\
\hline ROA & 0.0000 \\
\hline BOPO & 0.0000 \\
\hline FDR & 0.0000 \\
\hline
\end{tabular}

Uji Lag Length

Berdasarkan tabel 6, dapat dilihat hasil lag yang digunakan untuk model pengujian selanjutnya yaitu lag 2. Hal ini dikarenakan nilai LR, FPE dan AIC terkecil diantara lag yang lain ditandai dengan adanya tanda bintang terdapat pada lag 2.

Tabel 6

Hasil Uji Lag Length

\begin{tabular}{cccll}
\hline Lag & LogL & LR & \multicolumn{1}{c}{ FPE } & \multicolumn{1}{c}{ AIC } \\
\hline 0 & -268.0831 & NA & 2.761951 & 12.36741 \\
1 & -162.4349 & 187.2854 & 0.047120 & 8.292496 \\
2 & -145.7029 & $26.61906^{*}$ & $0.046474^{*}$ & $8.259224^{*}$ \\
3 & -131.6114 & 19.85625 & 0.053242 & 8.345973 \\
4 & -117.1573 & 17.73916 & 0.062911 & 8.416240 \\
\hline
\end{tabular}

\section{Uji Kausalitas Granger}

Sumber: Output EViews 6 (data diolah)

Berdasarkan tabel 7 dapat dilihat hasil uji kausalitas granger pada lag 2 menyebutkan bahwa tidak terdapat hubungan kausalitas dua arah diantara variabel-variabel yang diamati. Sebagian variabel yang diamati hanya memiliki hubungan kausalitas satu arah dan sebagian lainnya tidak memiliki hubungan kausalitas. Hubungan kausalitas satu arah terjadi pada hubungan Y(CAR) yang mempengaruhi $\mathrm{X}_{2}$ (BOPO) dan $\mathrm{X}_{3}$ (FDR) mempengaruhi Y(CAR) dengan $\alpha=5 \%$. Sedangkan antarvariabel lainnya tidak menunjukan adanya hubungan kausalitas. 
Tabel 7. Hasil Uji Kausalitas Granger Lag 2

\begin{tabular}{lrrr}
\hline Null Hypothesis: & Obs F-Statistic & Prob. \\
\hline X1 does not Granger Cause Y & 46 & 2.74664 & 0.0760 \\
Y does not Granger Cause X1 & & 1.10341 & 0.3414 \\
X2 does not Granger Cause Y & 46 & 0.32676 & 0.7231 \\
Y does not Granger Cause X2 & & 9.47252 & 0.0004 \\
X3 does not Granger Cause Y & 46 & 4.48461 & 0.0173 \\
Y does not Granger Cause X3 & & 0.48462 & 0.6194 \\
X2 does not Granger Cause X1 & 46 & 0.77291 & 0.4683 \\
X1 does not Granger Cause X2 & & 2.49921 & 0.0946 \\
X3 does not Granger Cause X1 & 46 & 0.18660 & 0.8305 \\
X1 does not Granger Cause X3 & & 1.11749 & 0.3369 \\
X3 does not Granger Cause X2 & 46 & 1.09164 & 0.3452 \\
X2 does not Granger Cause X3 & & 5.40853 & 0.0082 \\
\hline \multicolumn{2}{c}{ Sumber: Output EViews 6 (data diolah) }
\end{tabular}

\section{Uji Kointegrasi}

Berdasarkan tabel 8 dapat dilihat bahwa nilaiTrace Statistic sebesar 75,10663 lebih besar dibandingkan dengan nilai kritis pada tingkat keyakinan 5\% yaitu sebesar 63,87610, hal tersebut menunjukan bahwa terjadi kointegrasi antarvariabel pada tingkat keyakinan 5\%. Sehingga dapat dilanjukan ke model VECM.

Tabel 8. Hasil Uji Kointegrasi

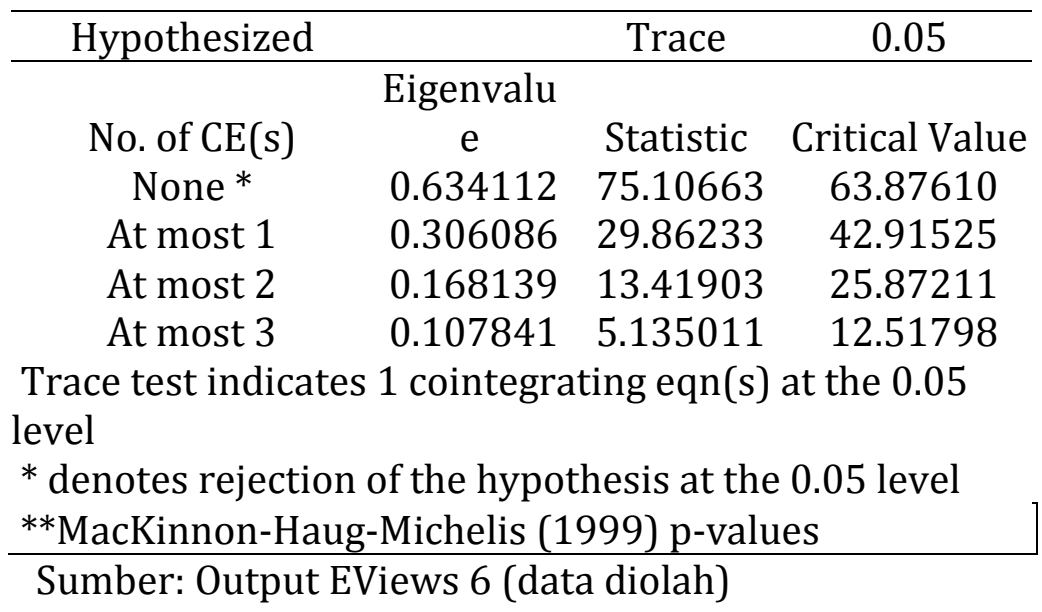

\section{Estimasi VECM}

Berdasarkan hasil uji VECM pada lag 2 dengan t-tabel sebesar 1,684 dihasilkan nilai t-hitung ROA sebesar 6.58706, BOPO sebesar 14.5920 dan FDR sebesar -6.14056 ketiga nilai t-hitung variabel-variabel tersebut lebih besar dibandingkan dengan nilai t-tabel. Oleh karena itu dapat dilihat bahwa ROA, BOPO dan FDR memiliki hubungan jangka pendek dengan CAR. Sedangkan dalam jangka panjang, hanya variabel BOPO periode $\mathrm{t}-2$ dan FDR periode $\mathrm{t}-2$ yang memiliki hubungan dengan nilai t-hitung yang lebih besar dibandingkan t-tabelnya. Sedangkan ROA menunjukan tidak adanya hubungan jangka panjang dengan CAR karena nilai t-hitungnya yang lebih kecil dibanding t-tabel. 


\section{Uji IRF (Impulse Response Function)}

Uji IRF bertujuan untuk melihat gambaran pergerakan variabel yang disebabkan adanya shock variabel lain. IRF pada penelitian ini difokuskan untuk melihat respon nilai CAR terhadap shock (perubahan) variabel ROA, BOPO dan FDR Bank Syariah Mandiri. Uji IRF ini dtunjukan dengan grafik.

Berdasarkan hasil uji IRF menunjukan respon CAR terhadap shock (perubahan) nilai variabel ROA, BOPO dan FDR Bank Syariah Mandiri yaitu sebagai berikut: Pertama, respon CAR terhadap shock (perubahan) ROA dalam jangka waktu 48 bulan menunjukan respon yang negatif. Grafik IRF menunjukan respon CAR bulan ke-1 (Januari 2009) hingga bulan ke-10 (Oktober 2009) negative fluktuatif, sedangkan bulan ke-11 (November 2009) hingga bulan ke-48 (Desember 2012) negatif dan stabil. Secara terperinci jika dilihat dari tabel nilai respon CAR terhadap perubahan nilai ROA yaitu pada awal titik keseimbangan dan menunurun menjadi -0.198465 pada periode kedua. Penurunan tersebut terjadi hingga periode ke-48 dan nilai responnya menjadi -0.153182. Artinya, setiap perubahan kenaikan 1\% ROA akan menurunkan CAR hingga 0,15\%.

Kedua, respon CAR terhadap shock (perubahan) BOPO dalam jangka waktu 48 bulan menunjukan respon yang positif. Grafik IRF menunjukan respon CAR bulan ke-1 (Januari 2009) hingga bulan ke-12 (Desember 2009) positif fluktuatif, sedangkan bulan ke-13 (Januari 2010) hingga bulan ke-48 (Desember 2012) positif dan stabil. Secara terperinci jika dilihat dari tabel nilai respon CAR terhadap perubahan nilai BOPO yaitu pada awal titik keseimbangan dan meningkat menjadi 0.105167 pada periode kedua. Peningkatan tersebut terjadi hingga periode ke-48 dan nilai responnya menjadi 0,134466 . Artinya, setiap perubahan kenaikan $1 \%$ BOPO akan menaikan CAR hingga 0,14\%.

Ketiga, respon CAR terhadap shock (perubahan) FDR dalam jangka waktu 48 bulan menunjukan respon yang negatif. Grafik IRF menunjukan respon CAR bulan ke-1 (Januari 2009) hingga bulan ke-5 (Mei 2009) negatif fluktuatif, sedangkan bulan ke-6 (Juni 2009) hingga bulan ke-48 (Desember 2012) negatif dan stabil. Secara terperinci jika dilihat dari tabel nilai respon CAR terhadap perubahan nilai ROA yaitu pada awal titik keseimbangan dan menunurun menjadi -0.166459 pada periode kedua. Penurunan tersebut terjadi hingga periode ke-48 dan nilai responnya menjadi -0.008459 . Artinya, setiap perubahan kenaikan 1\% FDR akan menurunkan CAR hingga 0,008\%.

\section{Uji Variance Decomposition}

Uji variance decomposition atau disebut juga forecast error variance decompotition bertujuan untuk memberikan informasi mengenai proporsi dari pergerakan pengaruh shock pada sebuah variabel terhadap shock variabel lainnya pada periode saat ini dan yang akan datang.

Berdasarkan grafik dan tabel diatas dapat dilihat hasil uji variance decomposition menunjukan kontribusi nilai variabel ROA, BOPO dan FDR dalam menjelaskan variabel CAR Bank Syariah Mandiri yaitu sebagai berikut: Pertama, kontribusi nilai ROA dalam menjelaskan variabilitas CAR pada periode kedua sebesar 4,64\%. Kontribusi ROA dalam menjelaskan variabilitas CAR tersebut terus meningkat hingga periode ke-48 mendatang menjadi 6,72\%. Kedua, kontribusi nilai BOPO dalam menjelaskan variabilitas CAR pada periode kedua sebesar 1,30\%. Kontribusi BOPO dalam menjelaskan variabilitas CAR tersebut terus meningkat hingga periode ke-48 mendatang menjadi 5,25\%. Ketiga, kontribusi nilai FDR dalam menjelaskan variabilitas CAR pada periode kedua sebesar 3,26\%. 
Kontribusi FDR dalam menjelaskan variabilitas CAR tersebut menurun hingga periode ke-48 mendatang menjadi 0,18\%.

Data variabel CAR, ROA, BOPO dan FDR stasioner pada tingkat diferensiasi 1 (first difference), sehingga menyebabkan data terkointegrasi yang menunjukan adanya stabilitasnya hubungan jangka panjang antarvariabel penelitian tersebut. Selain itu, hubungan kausalitas antara CAR, ROA, BOPO dan FDR tidak terdapat hubungan kausalitas dua arah. Berdasarkan pengujian terlihat yang ada hanya hubungan searah. Oleh karena itu, dilakukan uji VECM untuk melihat pengaruh antarvariabel penelitian ini. Berdasarkan uji IRF menunjukan respon CAR terhadap perubahan yang terjadi pada ROA secara negatif dan respon tersebut terjadi hingga periode ke-48 dengan nilai respon menjadi -0.153182 . Artinya, setiap perubahan kenaikan 1\% ROA akan menurunkan CAR hingga 0,15\%. Selain itu kontribusi nilai ROA dalam menjelaskan variabilitas CAR terus meningkat hingga periode ke-48 mendatang menjadi 6,72\%.

Berdasarkan hasil penelitian tersebut dapat disimpulkan Ho 1 ditolak yang berarti ROA berpengaruh signifikan negatif terhadap CAR Bank Syariah Mandiri. Selain itu, berdasarkan hasil uji VECM menyebutkan terdapat hubungan jangka pendek yang positif antara ROA dengan CAR BSM, sedangkan dalam jangka panjang tidak terdapat hubungan yang signifikan antara ROA dengan CAR sehingga Ho 4 ditolak.

Hasil penelitian tersebut sesuai dengan hasil penelitian F. Artin Shitawati dan teori yang dikemukakan oleh Masyhud Ali tentang adanya pengaruh ROA dengan CAR, yang membedakanya adalah hubungan tersebut, dimana berdasarkan hasil penelitian ini terdapat hubungan negatif sedangkan berdasarkan penelitian terdahulu dan teori menjelaskan adanya hubungan positif. Hasil penelitian F. Artin Shitawati tersebut menyebutkan bahwa ROA secara parsial berpengaruh signifikan positif terhadap CAR Bank Umum di Indonesia. Selain itu, Masyhud Ali (2006) mengemukakan teori bahwa setiap kali bank mengalami kerugian, modal bank menjadi berkurang nilainya dan sebaliknya jika bank meraih untung maka modalnya akan bertambah.

Hubungan negatif antara ROA dengan CAR dalam penelitian ini menunjukan bahwa ROA yang tinggi menurunkan nilai CAR Bank Syariah Mandiri. Hal ini mengindikasikan tingginya laba tersebut bisa berasal dari modal yang digunakan untuk meningkatkan laba Bank Syariah Mandiri itu sendiri, selain itu dapat diindikasikan bahwa peningkatan laba Bank Syariah Mandiri tidak disimpan dalam modal cadangan, sehingga laba tidak mampu meningkatkan CAR. Hal ini bisa terjadi dikarenakan tingginya ekspansi pembiayaan, sehingga laba yang diperoleh digunakan untuk permintaan pembiayaan tersebut.

Respon CAR terhadap shock (perubahan) BOPO dalam jangka waktu 48 bulan menunjukan respon yang positif. Peningkatan tersebut terjadi hingga periode ke-48 dan nilai responnya menjadi 0,134466. Artinya, setiap perubahan kenaikan 1\% BOPO akan menaikan CAR hingga 0,14\%. Kontribusi BOPO dalam menjelaskan variabilitas CAR tersebut terus meningkat hingga periode ke-48 mendatang menjadi 5,25\%.

Berdasarkan hasil penelitian dapat disimpulkan Ho 2 ditolak yang berarti BOPO berpengaruh signifikan positif terhadap CAR Bank Syariah Mandiri. Selain itu, berdasarkan etsimasi VECM diperoleh hasil terdapat hubungan jangka pendek maupun jangka panjang yang positif antara BOPO dengan CAR BSM, sedangkan dalam jangka panjang tidak terdapat hubungan yang signifikan antara BOPO 
dengan CAR sehingga Ho 4 ditolak. Hasil penelitian ini sesuai dengan penelitian F. Artin Shitawati yang menyebutkan bahwa BOPO berpengaruh signifikan negatif terhadap CAR dan Faisal Abdullah (2003) yang menyatakan semakin besar BOPO menunjukan kurang efisiennya bank dalam menjalankan kegiatan operasionalnya karena biaya operasional yang harus ditanggung lebih besar dari pada pendapatan operasional yang diperoleh sehingga ada kemungkinan modal digunakan untuk menutupi biaya operasional yang tidak tertutup oleh pendapatan operasional.

Perbedaan hasil penelitian ini dengan penelitian sebelumnya dan teori yang ada yaitu terletak pada hubungan yang positif antara BOPO dengan CAR mengindikasikan bahwa saat BOPO tinggi maka CAR akan meningkat, begitupun sebaliknya saat BOPO turun CAR akan menurun. Hal ini dikarenakan BOPO yang tinggi mengindikasikan kurang efisiennya bank dalam menghasilkan labanya menggunakan biaya operasional, sehingga dapat dilihat bahwa modal tidak digunakan dalam usaha bank untuk mengefisienkan pendapatan perasional melalui biaya operasional.

Respon CAR terhadap shock (perubahan) FDR dalam jangka waktu 48 bulan menunjukan respon yang negatif. Penurunan tersebut terjadi hingga periode ke-48 dan nilai responnya menjadi -0.008459 . Artinya, setiap perubahan kenaikan $1 \%$ FDR akan menurunkan CAR hingga 0,008\%. Kontribusi FDR dalam menjelaskan variabilitas CAR tersebut menurun hingga periode ke-48 mendatang menjadi $0,18 \%$.

Sehingga dapat disimpulkan Ho 3 ditolak yang berarti FDR berpengaruh signifikan positif terhadap CAR Bank Syariah Mandiri. Berdasarkan etsimasi VECM diperoleh hasil terdapat hubungan jangka pendek yang signifikan negatif, sedangkan jangka panjang terdapat hubungan yang signifikan positif antara BOPO dengan CAR BSM, sehingga dapat disimpulkan Ho 4 ditolak.

Hasil penelitian ini sesuai dengan penelitian F. Artin Shitawati yang menyebutkan bahwa BOPO berpengaruh signifikan negatif terhadap CAR dan teori Faisal Abdullah yang menyatakan suatu bank yang memiliki alat-alat likuid yang sangat terbatas dalam memenuhi kewajiban-kewajibannya, akan ada kemungkinan penyediaan likuiditas tersebut akan diambil dari permodalannya (Abdullah, 2003).

Hubungan yang negatif antara FDR dengan CAR mengindikasikan bahwa saat FDR tinggi maka CAR akan menurun, begitupun sebaliknya saat FDR turun CAR akan naik. Hal ini dikarenakan jumlah pembiayaan yang disalurkan Bank Syariah Mandiri sangat tinggi sehingga terjadi ekspansi pembiayaan yang mengharuskan bank menambahkan dananya melalui modal sendiri untuk membiayai jumlah pembiayaan yang disalurkan dan memenuhi likuiditasnya.

\section{SIMPULAN}

Berdasarkan hasil yang didapat, menunjukkan bahwa ROA, BOPO dan FDR berpengaruh secara parsial terhadap CAR Bank Syariah Mandiri. ROA berpengaruh secara parsial terhadap CAR Bank Syariah Mandiri sehingga hipotesis (Ho 1) ditolak. Pengaruh ROA terhadap CAR ini merupakan pengaruh yang negatif signifikan. Dimana, ketika nilai ROA tinggi maka akan terjadi penurunan nilai CAR, begitupun sebaliknya. Variabel CAR dapat dijelaskan oleh ROA sebesar 6,72\%.

BOPO berpengaruh secara parsial terhadap CAR Bank Syariah Mandiri sehingga Hipotesis (Ho 2) ditolak. Pengaruh BOPO terhadap CAR ini merupakan pengaruh yang positif signifikan. Dimana, ketika nilai BOPO tinggi maka akan 
terjadi peningkatan nilai CAR, begitupun sebaliknya. Variabel CAR dapat dijelaskan oleh BOPO sebesar 5,25\%.

FDR berpengaruh secara parsial terhadap CAR Bank Syariah Mandiri sehingga Hipotesis (Ho 3) ditolak. Pengaruh FDR terhadap CAR ini merupakan pengaruh yang negatif signifikan. Dimana, ketika nilai FDR tinggi maka akan terjadi penurunan nilai CAR, begitupun sebaliknya. Variabel CAR dapat dijelaskan oleh FDR sebesar $0,008 \%$.

Hubungan ROA dengan CAR dalam jangka pendek yaitu hubungan yang positif, sedangkan dalam jangka panjang tidak terdapat hubungan (pengaruh) antara ROA dengan CAR Bank Syariah Mandiri. Hubungan BOPO dengan CAR dalam jangka pendek maupun jangka panjang yaitu hubungan yang signifikan positif. Hubungan FDR dengan CAR dalam jangka pendek yaitu hubungan yang signifikan negatif, sedangkan dalam jangka panjang terdapat hubungan (pengaruh) signifikan positif antara FDR dengan CAR Bank Syariah Mandiri.

\section{PUSTAKA ACUAN}

Abdullah, Faisal. 2003. Manajemen Perbankan (Teknik Analisis Kinerja Keuangan Bank). Malang: Universitas Muhammadiyah Malang (UMM) Press

Al Arif, M. N. R. 2012. Lembaga Keuangan Syariah: Kajian Teoritis Praktis. Bandung: Pustaka Setia

Ali, Masyhud. 2006. Manajemen Risiko: Strategi Perbankan dan Dunia Usaha Menghadapi Tantangan Globalisasi Bisnis. Jakarta: PT RajaGrafindo Persada

Artin, F. S. 2006. "Analisis Faktor-Faktor yang berpengaruh terhadap Capital Adequecy Ratio (Studi Empiris: Bank Umum di Indonesia periode 20012004)". Tesis S2 Program Studi Magister Manajemen, Universitas Diponegoro

Dendawijaya, Lukman. 2005. Manajemen Perbankan (edisi kedua). Bogor: Ghalia Indonesia

Fitriyani, Mena. 2011. "Faktor-Faktor yang mempengaruhi Capital Adequecy Ratio pada Bank Umum Syariah di Indonesia periode 2006-2009”. Skripsi S1 Fakultas Syariah dan Hukum, Universitas Islam Negeri Sunan Kalijaga

Hasibuan, Malayu S.P. 2006. Dasar-Dasar Perbankan. Jakarta: PT Bumi Aksara

Kasmir. 2003. Manajemen Perbankan. Jakarta: PT. Raja Grafindo Persada

-------. 2009. Analisis Laporan Keuangan. Jakarta : PT. Rajawali Press

-------. 2008. Bank dan Lembaga Keuangan Lainnya. Jakarta: PT RajaGrafindo Persada

Kuncoro, Mudrajad. 2003. Metode Riset untuk Bisnis dan Ekonomi. Jakarta: Erlangga

Kuncoro, Mudrajad dan Suhardjono. 2002. Manajemen Perbankan Teori dan Aplikasi. Edisi Pertama. Yogyakarta: BPFE Yogyakarta

Laurence, A. M. 2002. "Analisis Pengaruh Rentabilitas terhadap Rasio Kecukupan Modal Pada Bank Tabungan Pensiunan Nasional",MediaRiset Bisnis dan Manajemen, Vol.2, No.1, 2002, pp.26 - 47.

Martono. 2002. Bank dan Lembaga Keuangan Lain. Edisi Pertama. Yogyakarta: Penerbit Ekosinia

Mustofa. 2009. "Analisa Pengakuan Laba Dalam Perbankan Syariah dan Pengaruhnya Terhadap CAR". Skripsi S1 Fakultas Syariah dan Hukum, Universitas Islam Negeri Syarif Hidyatullah Jakarta

Nachrowi,N. D dan Hardius Usman. 2008. Penggunaan Teknik Ekonometri: Pendekatan Popular dan Praktis Dilengkapi Teknik Analisis dan Pengolahan Data dengan Menggunakan Paket Program SPSS. Jakarta: PT. Raja Grafindo Persada 
Noris, S. U. 2011. "Analisis Pengaruh LDR, NPL dan Inflasi terhadap CAR serta implikasinya terhadap penyaluran kredit di Bank Persero". Skripsi S1 Fakultas Ekonomi dan Bisnis, Universitas Islam Negeri Syarif Hidyatullah Jakarta

Peraturan Bank Indonesia Nomor: 6/10/PBI/2004 tentang Sistem Penilaian Tingkat Kesehatan Bank Umum.

Peraturan Bank Indonesia Nomor: 7/13/PBI/2005 tanggal 10 Juni 2005 tentang Kewajiban Penyediaan Modal Minimum Bank Umum Berdasarkan Prinsip Syariah.

Riyadi, Slamet. 2004. Banking Asset and Liability Management. Jakarta: Fakultas Ekonomi UI

Rohamtul, S. A. 2011. Cara Cerdas Menguasai EViews. Jakarta: Salemba Empat

Siamat, Dahlan. 2004. Manajemen Lembaga Keuangan (edisi keempat). Jakarta: Fakultas Ekonomi Universitas Indonesia

Soeratno dan L. Arsyad. 2003. Metodologi Penelitian untuk Ekonomi dan Bisnis. Yogyakarta: UPP Akademi Manajemen Perusahaan YKPN

Suhirman. 2001. Kajian Tentang Perkembangan LDR dan Dampaknya bagi Rentabilitas Bank. Jakarta: Institut Bankir Indonesia

Teguh, Muhamad. 2005. Metodologi Penelitian Ekonomi Teori dan Aplikasi, Jakarta: PT. Raja Grafindo Persada

Winarno, W Wahyu. 2007. Ekonometrika dan statistik dengan eviews. Yogyakarta: Sekolah Tinggi Ilmu Manajemen YKPN 